Article - Engineering, Technology and Techniques

\title{
Bioethanol from Microalgal Biomass: A Promising Approach in Biorefinery
}

\author{
Carlos Eduardo de Farias Silva ${ }^{1,2}$ \\ https://orcid.org/0000-0002-1462-1145 \\ Alberto Bertucco ${ }^{2}$ \\ https://orcid.org/0000-0002-3923-0618 \\ ${ }^{1}$ University of Alagoas, Center of Technology, Maceió, Alagoas, Brazil; ${ }^{2}$ University of Padova, \\ Department of Industrial Engineering, Padova, Padova, Italy.
}

Received: 2016.08.26; Accepted: 2017.10.23

*Correspondence: eduardo.farias.ufal@gmail.com, +55-82-98761-7765

\section{HIGHLIGHTS}

- Microalgae can decrease food vs fuel issues;

- Acidic and enzymatic hydrolysis are the most applied for ethanol production;

- Hydrothermal liquefaction and flash hydrolysis are alternative processes;

- Biogas from vinasse can be an important alternative in energy production and nutrient recycling

\begin{abstract}
The development of new technologies which increase the production of biofuel without directly compete with food production is required. Microalgal biomass has recently been in the highlight. The role of this biomass is here discussed within the concept of biorefinery and industrial sustainability of bioethanol production. The process of cultivation in order to accumulate around $50 \%$ of carbohydrates in the biomass (dry weight) and the importance of water and nutrient recycling are reviewed. Saccharification of biomass using enzymes or acids and alternative processes such as hydrothermal liquefaction and flash hydrolysis are addressed. Since the main monosaccharide in microalgal biomass is glucose, high rates of hydrolysis and fermentation were, generally, achieved (more than $80 \%$ of the efficiency as a sum of these two processes). Anaerobic digestion to treat vinasse and the recycling of $\mathrm{CO} 2$ from the ethanolic fermentation and biogas could increase the process sustainability. Alternative techniques for the concentration of bioethanol from fermentation broth and for the optimization of fuel transportation are mentioned. Finally, the advantage of using microalgae rather than other sources is estimated with reference to the production rate, even though the cultivation costs are still high.
\end{abstract}

Keywords: ethanol, microalgae, biofuel, hydrolysis, nutrient recycle. 


\section{INTRODUCTION}

Increasing and improving global strategies for energy security and mitigation of $\mathrm{CO}_{2}$ emissions from energy production processes are required, especially those aimed at maximizing the energy efficiency by expanding the use of clean energy, i.e., the use of fuels that promote the carbon cycle without changing the atmospheric balance (renewable fuels), and the development of energetic resources in $\mathrm{CO}_{2}$ neutral systems [1].

The use of natural resources involves economic activities in developed and in developing countries, especially industrial and agricultural activities, with numerous studies, investments and achievements in clean technologies, resource saving, recycling and reuse of wastes [2]. In particular, biofuels have an important role in reducing global climate change and their impact will depend on several aspects related to the choice of new technologies, legal restrictions, international trade, land use, choice of raw materials and management techniques [3].

\section{BIOETHANOL PRODUCTION}

Bioethanol production is currently classified as belonging to the first (raw material saccharine or starch-based), second (lignocellulosic materials) and third biofuel generation (microalgal biomass), which differ according to the process and raw materials used. Fourth generation bioethanol is an emerging technology and refers specifically to the production of ethanol without biomass breakdown, i.e., to cyanobacteria genetically modified to capture sunlight, water and nutrients and convert them directly into ethanol by a process known as 'photofermentation'.

Figure 1 represents the main stages of each of these schemes in bioethanol production. First generation bioethanol is obtained from food materials rich in soluble sugars, or starch-based food. Its disadvantages comprise the need of large extensions of land, a season-limited production, the use of fertilizers and pesticides, the reduction of soil biodiversity causing erosion, and especially the competition for land with food production. However, the technology is well established and has lower production costs, so that it is economically sustainable. Second generation bioethanol is based on lignocellulosic materials with greater saccharification difficulties, due to the cellulose and lignin presence. Specifically, lignin is a recalcitrant and non-fermentable compound. High production rates associated with violent pretreatments and use of several enzymes, in order to enhance the naturally low productivity, make the process difficult to find large scale consolidation with acceptable production costs. In third generation bioethanol, microalgae biomass is used, which does not have lignin in its cellular structure, and is cultivated with higher growth rates when compared to higher plants [4-6]. Eventually, genetically modified cyanobacteria are patented applications, and little information has been released and discussed in literature [7].

Low costs are proper to first generation bioethanol (with the exception of corn-based), while the second generation requires a decrease in production costs to become competitive [8]. In the case of third and fourth generation bioethanol, further studies 
are required to develop a competitive and consolidated technology, taking into account also issues other the technological ones.

In this paper, we suggest the idea that it should be more correct to address the issue of bioethanol production from the biorefinery standpoint. Sugar cane, the main raw material used in bioethanol production processes, has the lowest costs. In spite of its significant advantage, it is not a viable option for all the regions of the planet. Consequently, countries of the northern hemisphere have been incessantly looking for new technological routes that permit the production of efficient biofuels while respecting environmental and economic sustainability issues [9].

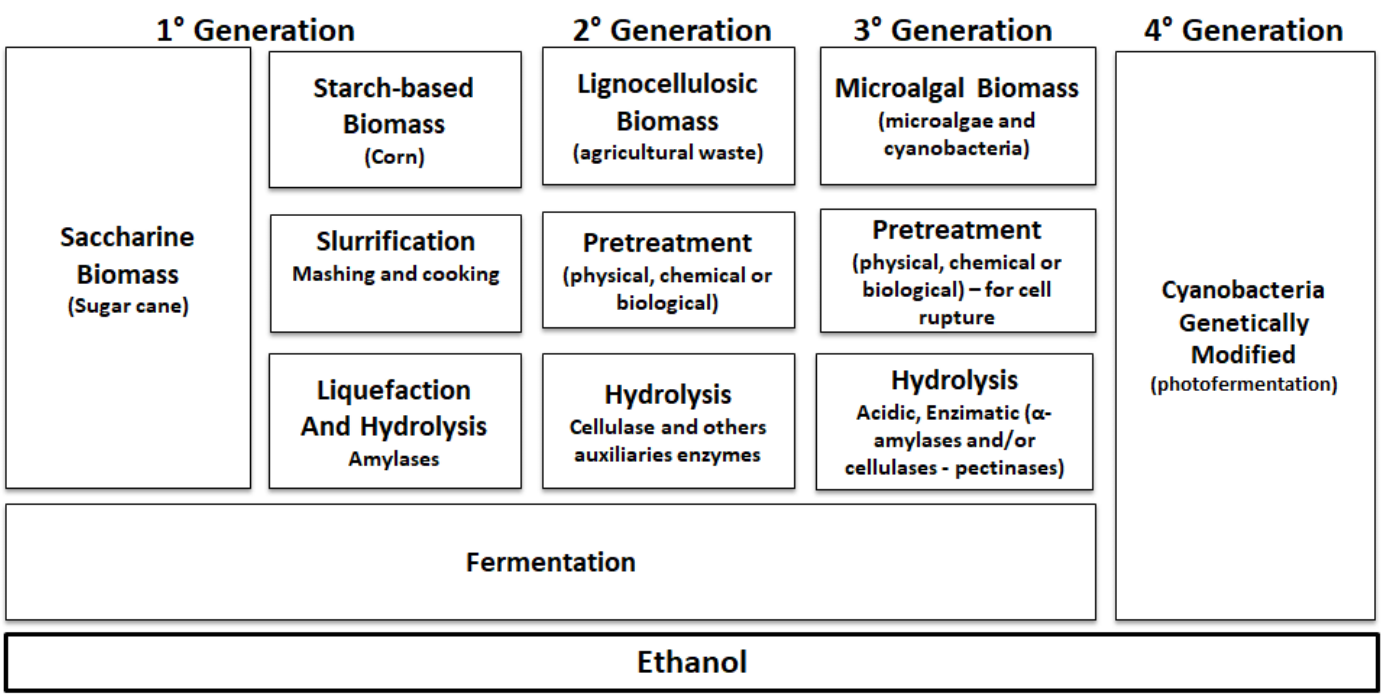

Figure 1: Main steps of the four generations to bioethanol production.

Among other definitions, the International Energy Agency (IEA Bioenergy) defines biorefining as "the sustainable processing of biomass into a spectrum of marketable products and energy" [10]. The National Renewable Energy Laboratory (NREL) comments that "biorefinery is a facility that integrates biomass conversion processes and equipment to produce fuels, power and chemicals from biomass" [11]. As a rule, biorefinery is the integration of a given biomass, with all its components separated, to produce energy and chemicals. Biorefineries enlarge and spread the concept of biofuels, energy and chemicals from a renewable source and promote the concept of carbon cycle, aiming at sustainability, while helping in the reduction of production costs.

This concept can be applied to bioethanol production processes from microalgal biomass as proposed in Figure 2 . The different units of this block flow diagram will be discussed separately.

\section{CULTIVATION AND ACCUMULATION OF CARBOHYDRATES}

Microalgae must ensure a high production rate of carbohydrates that can be latter fermented into bioethanol. Starch and glycogen are the main carbohydrate reserve forms in microalgae and cyanobacteria, respectively. Namely, nutritional techniques (nutrient starvation and carbon source), saline stress, light intensity and temperature [12,13], can be applied to this purpose. As a rule, nitrogen limitation is one of the most efficient techniques. Under nitrogen restriction, or starvation, microalgae degrade their $\mathrm{N}$-based macromolecules 
as proteins with the accumulation of carbohydrates and lipids [14]. As shown in Figure 3, after nitrogen restriction the breeding of several microalgae species accumulates carbohydrates with maximum fraction of dry cell weight between $50-55 \%$.

\section{HARVESTING}

The most applied methods comprise flocculation, coagulation, gravitational sedimentation, electric-based processes, filtration and centrifugation [15]. Gravitational sedimentation, flocculation and centrifugation usually have high yields and lower costs.

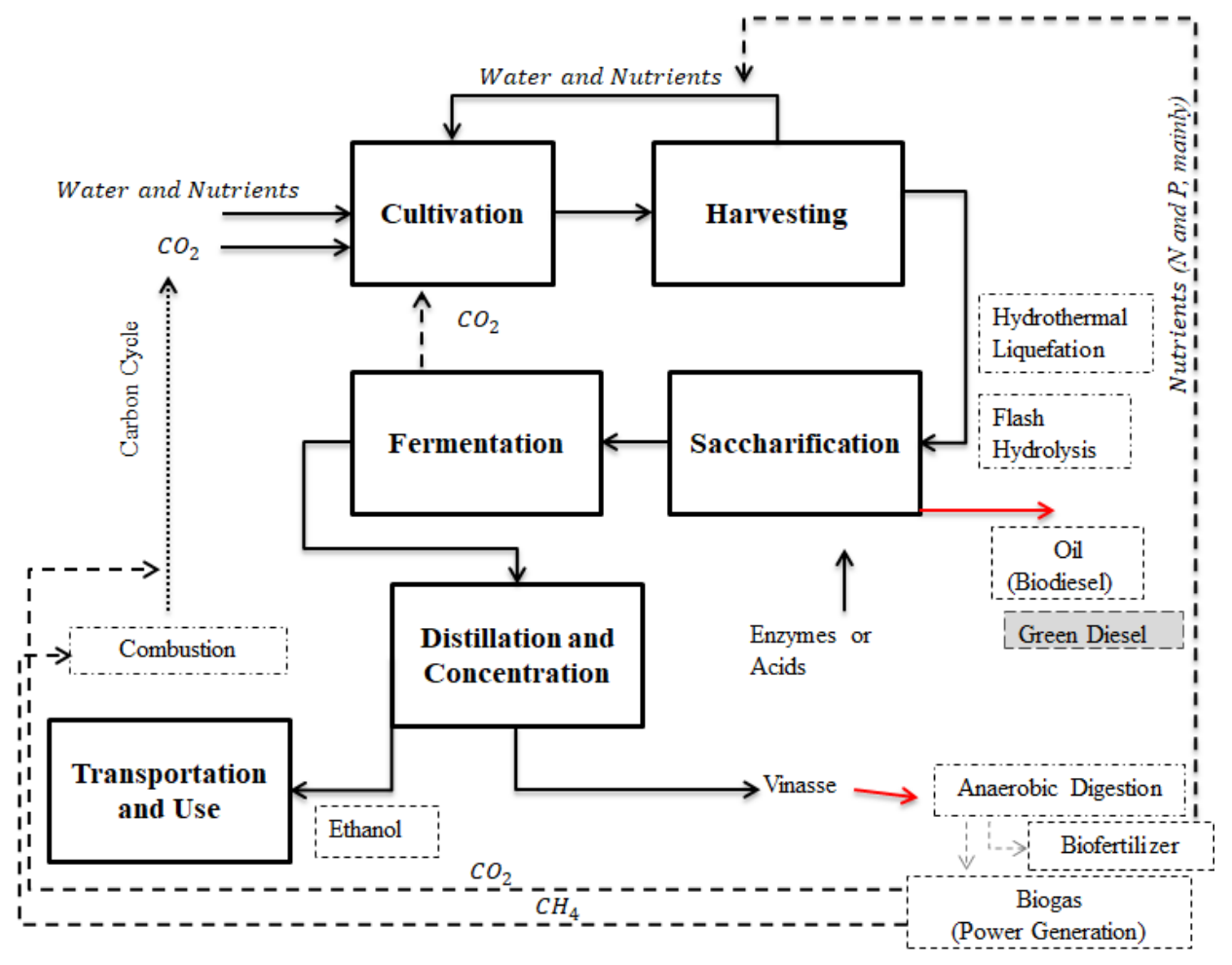

Figure 2: Flow chart of bio-ethanol production from microalgae biomass within the concept of biorefinery.

\section{WATER AND NUTRIENT RECYCLE AFTER CULTIVATION}

Water and nutrient recycling in the process, especially after the cultivation of microorganisms, is an essential stage to make biofuels processes environmentally and economically sustainable, as it warrants a better use of available nutrients, with an increase in the process yield. Losses with evaporation, harvesting and cleaning need to be quantified. Generally, between 1500-3000 L of water are necessary to produce $1 \mathrm{~L}$ of biodiesel and, when recycling is used, its value is substantially decreased to a range between $500-800 \mathrm{~L}$ (experimental results for Chlorella vulgaris) [16]. In relation to nutrients, it is necessary to control, especially, the correct use of macronutrients such as nitrogen, phosphorus and sulfur, i.e., to quantify their concentrations in the effluent after cultivation. Nutrient recycling is the only alternative to promote their maximum utilization. 


\section{SACCHARIFICATION AND FERMENTATION}

Saccharification may be of either chemical or enzymatic type, each one with its own advantages. The use of sulfuric, hydrochloric and nitric acid is effective in chemical saccharification although more aggressive conditions are required for hydrolysis, generally ranging between 120 and $140^{\circ} \mathrm{C}$ of temperature and between 15 and 30 min of reaction time, if $>80 \%$ saccharification and $>80 \%$ of theoretical fermentation yield are desired.

Acid hydrolysis of Scenedesmus obliquus at $120^{\circ} \mathrm{C}$ with $2-3 \mathrm{~N}$ sulfuric acid for $30 \mathrm{~min}$ practically provided the full hydrolysis of all carbohydrate content $(71-97 \%$ of carbohydrate content), with $65 \%$ made up of glucose, if a solid concentration between 20 and $500 \mathrm{~g} / \mathrm{L}$ is used [17]. Scenedesmus bijugatus (26\% carbohydrate content after lipid extraction), after acid hydrolysis with $\mathrm{H}_{2} \mathrm{SO}_{4}(0.36-1.08 \mathrm{~N})$ at $130^{\circ} \mathrm{C}, 45 \mathrm{~min}$, and $20 \mathrm{~g} / \mathrm{L}$ solid concentration, saccharified $84 \%$ of biomass sugars and resulted in $70 \%$ of bioethanol conversion [18]. Acidic treatment of Chlorella vulgaris FSP-E with sulfuric acid is a more efficient hydrolysis method than enzymatic treatment (with amylases and cellulases) [19], for this specie. Ho et al. (2013) reported that hydrolysis performed with $\mathrm{H}_{2} \mathrm{SO}_{4}\left(0.036-1.8 \mathrm{~N}\right.$ at $121^{\circ} \mathrm{C}$ for $\left.20 \mathrm{~min}\right)$ using 10-80 $\mathrm{g} / \mathrm{L}$ of biomass concentration caused $95 \%$ saccharification of the biomass's glucose content, and that approximately $90 \%$ of the theoretical fermentation yield was achieved in $12 \mathrm{~h}$, after further fermentation with Zymomonas mobilis ATCC $29191^{19}$. Arthrospira platensis was hydrolyzed by $\mathrm{H}_{2} \mathrm{SO}_{4}, \mathrm{HNO}_{3}, \mathrm{HCl}$ and $\mathrm{H}_{3} \mathrm{PO}_{4}(0.25-2.5 \mathrm{~N})$, or the combined use of them at $60-100^{\circ} \mathrm{C}$, and the best result, was $80 \%$ saccharification and $55 \%$ fermentation yield using Saccharomyces cerevisiae MV 92081 [20].

Enzymatic hydrolysis features mild temperatures and lower degradation risks. Enzymes used for the saccharification of microalgal biomass normally include amylases, cellulases and pectinases (separate or together) whilst cell disruption is required.

C. vulgaris was also subjected to different methods of cell disruption (autoclave, beadbeating, and sonication). It has been reported that the use of beadbeating combined with pectinase (from Aspergillus aculeatus) treatment increased between $45 \%$ and $70 \%$ the extraction of sugars, with a fermentation yield of $89 \%$ after $12 \mathrm{~h}$ with $\mathrm{S}$. cerevisiae KCTC 7906. Apparently, pectinase is a more effective enzyme compared with cellulases, amylases and xylanases [21], for this specie. Enzymatic hydrolysis and fermentation of Chlamydomonas reinhardtii (50 g/L of biomass concentration and $59.7 \%$ of carbohydrate content) by separated hydrolysis and fermentation (SHF) using amylases $(0.005 \%$ $\alpha$-amylase from Bacillus licheniformis at $90^{\circ} \mathrm{C}$ and $30 \mathrm{~min}$ to liquefaction and $0.2 \%$ glucoamylase from Aspergillus niger at $55^{\circ} \mathrm{C}$ and 30 min to saccharification, $\mathrm{pH}$ 4.5) achieved a $94 \%$ hydrolysis of carbohydrates in microalgae. Further fermentation using Saccharomyces cerevisiae S288C achieved a 60\% yield [22]. Synechococcus sp. PCC 7002 accumulated $60 \%$ of carbohydrate contents ( $3 \mathrm{~g} / \mathrm{L}$ of biomass concentration) under nitrate depletion conditions, and a hydrolysis yield of $80 \%$ was achieved after enzymatic treatment (lysozyme, and a-glucanases Liquozyme ${ }^{\circledR}$ SC DS and Spirizyme ${ }^{\circledR}$ Fuel). Further fermentation with $S$. cerevisiae resulted in an $86 \%$ ethanol yield when compared with theoretical maximum rate [23]. 
Chlorella vulgaris

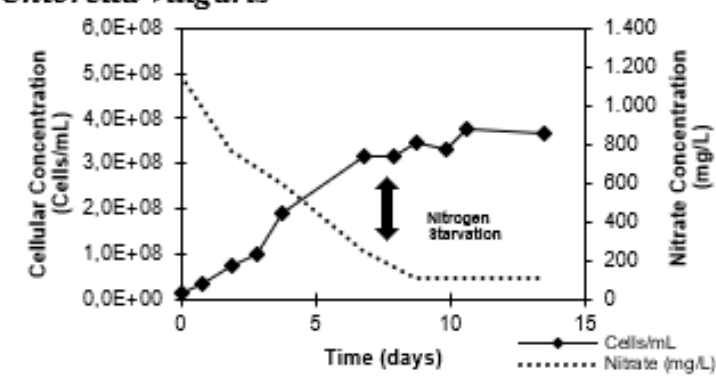

Chlorella prothotecoides

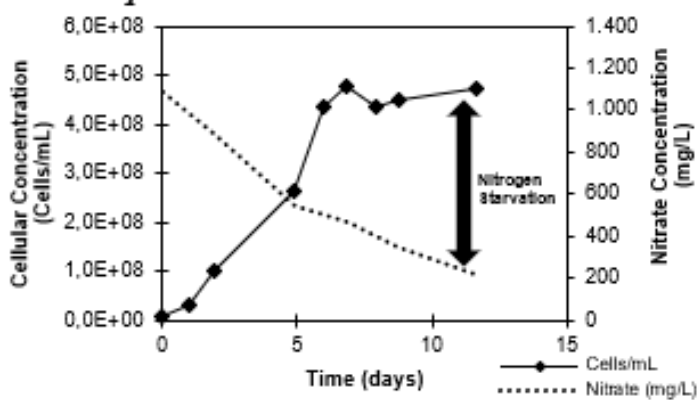

\section{Muriella zoofigiensis}

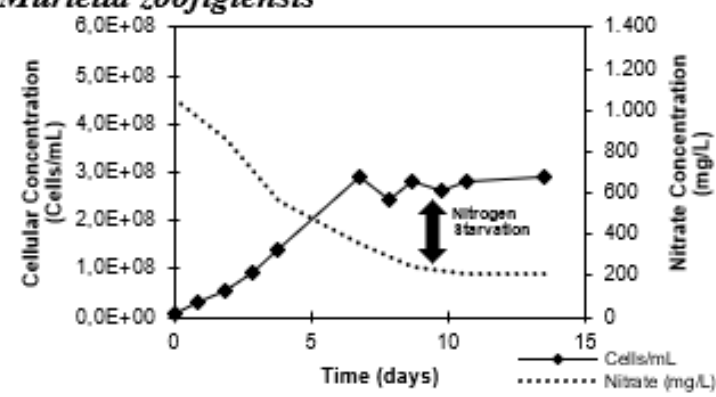

Scenedesmus obliquus

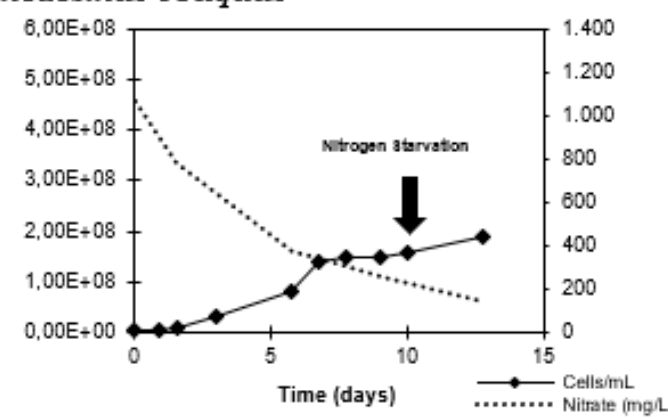

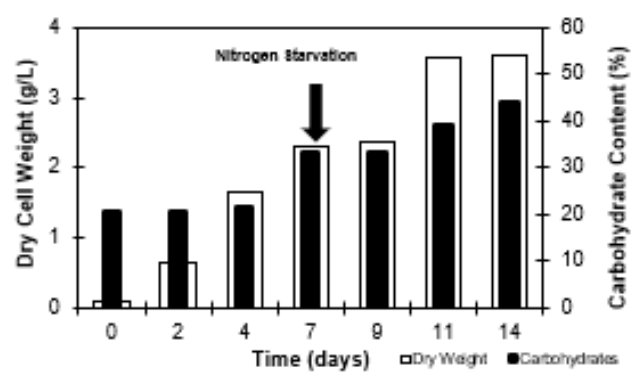
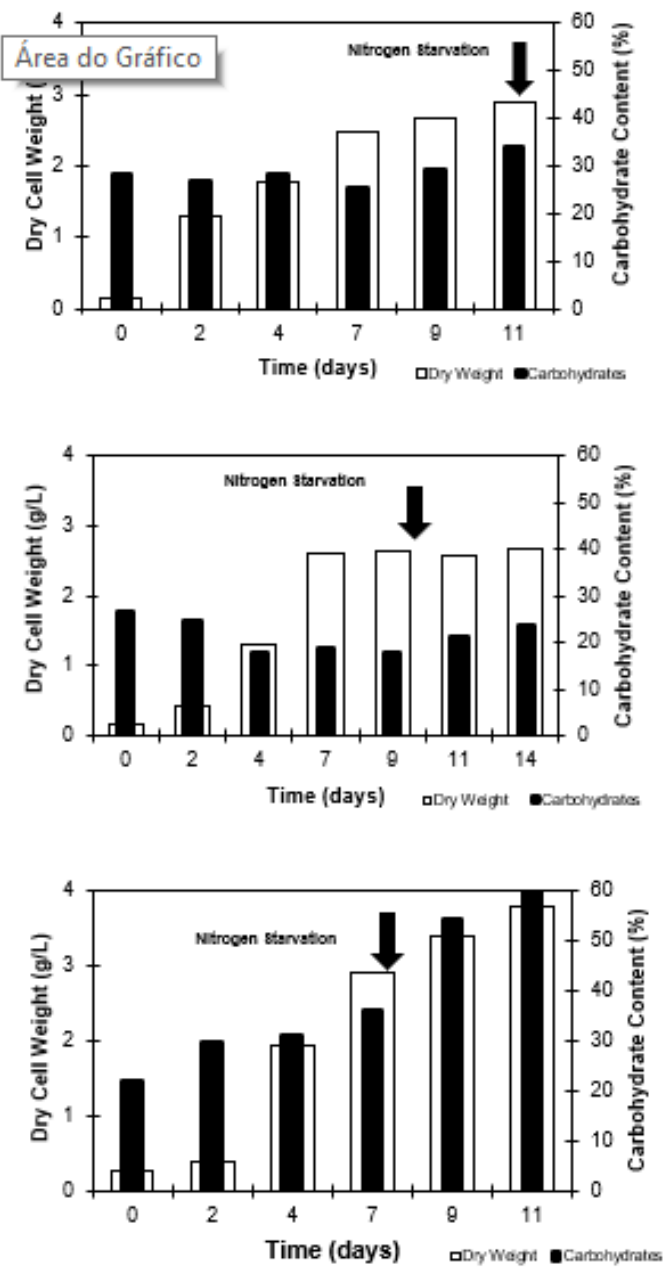

Figure 3: Screening of Microalgae Species with respect to Carbohydrate Accumulation. Species grown at $150 \mu \mathrm{mol}$ photons $/\left(\mathrm{m}^{2} \mathrm{~s}\right)$ and $28^{\circ} \mathrm{C}$. Chlorella vulgaris and Scenedesmus obliquus were more promising to bioethanol application due to the efficiency in carbohydrate accumulation close to $50 \%$ of carbohydrate content, in the cultivation conditions considered. Species were grown in medium BG-11 [24]. Dry cell weight (DCW) or dry weight was measured by using $0.45 \mu \mathrm{m}$ cellulose acetate filters $\left(\right.$ Whatman $\AA$ ). Filters were pre-dried for $10 \mathrm{~min}$ at $105^{\circ} \mathrm{C}$ to remove any moisture. Biomass was filtered and dried for $2 \mathrm{~h}$ at $105^{\circ} \mathrm{C}$ and then weighed to measure the dry weight, then expressed as grams per liter. The carbohydrate content was measured by the anthrone method [25]. Nitrate concentration (used as reference substrate) was determined by Kit Idrimetre St. Carlo Erba Reagenti®. 


\section{$\mathrm{CO}_{2}$ recycling}

The re-use of carbon dioxide in ethanol biorefineries is a must [26]. Alcohol fermentation has carbon dioxide and bioethanol as its final products. Carbon dioxide may be used in microalgae culture since they are photosynthetic microorganisms which fix inorganic carbon.

In the case of a microalgal biomass rich in carbohydrates (50\% carbohydrates, $20 \%$ lipids and $30 \%$ proteins and others), a direct recycling of $17 \%$ carbon dioxide fixed in the biomass cultivation is theoretically possible.

\section{PRODUCTION OF BIODIESEL}

This is an important aspect because chemical hydrolysis methods may also facilitate the solvent extraction of lipids, thereby recovering both fermentable sugars and lipids from the microalgal biomass.

Nannochloropsis gaditana, Chlorella sorokiniana and Phaeodactylum tricornutum have been treated by steam explosion with sulfuric acid $\left(\mathrm{H}_{2} \mathrm{SO}_{4}, 0-3.6 \mathrm{~N}\right.$ at $120-150^{\circ} \mathrm{C}$ for $\left.5 \mathrm{~min}\right)$, and approximately $96 \%$ of the sugar content was hydrolyzed using $0.6 \mathrm{~N}$ of the acid at $150^{\circ} \mathrm{C}$. The acid hydrolysis of these microalgae biomasses also increased the efficiency of lipid extraction [27]. Wang and coworkers reported a $25 \%$ increase in lipid contents obtained before and after hydrolysis of the microalgae Tribonema sp. with $\mathrm{H}_{2} \mathrm{SO}_{4} 1 \mathrm{~N}$. The carbohydrate content was hydrolyzed to $80 \%$ for a biomass concentration of $50 \mathrm{~g} / \mathrm{L}$ in suspension at $121^{\circ} \mathrm{C}$ and $45 \mathrm{~min}$, and $70 \%$ of the theoretical yield was achieved after fermentation with $S$. cerevisiae [28].

In this respect, a promising process is the so-called "green diesel production", which can be used instead of biodiesel, a process denominated Ecofining ${ }^{\mathrm{TM}}$ Process (vegetable oil refining) $[29,30]$. This patented process is claimed as a versatile solution for producing diesel and jet fuel from a range of sustainable feedstocks.

The advantages of the biofuel obtained in this way, in comparison to the traditional biodiesel, are the better performances in relation to corrosion problems, high density of the FAME and low blend limits, thus reducing costs and risks of compliance, implementing flexible feedstocks and obtaining high yields [31]. Another aspect is that the green diesel can be processed in the existing infrastructure of refineries.

A scheme of this process is presented in Figure 4, where it is possible to see that the amount of chemicals required is reduced in comparison to the biodiesel, which generally uses an alcohol and a catalyst (acid or alkali) to provide the transesterification. It is an integrated two-stage hydrorefining process.

In the first reactor, the recycled hydrogen is mixed with the feedstocks, and the renewable oil is saturated and totally deoxygenated. Selectivity to diesel boiling-range paraffins is very high. The primary deoxygenation reaction by-products are propane, water and carbon dioxide. The first reactor outlet is immediately separated at reactor pressure to remove carbon dioxide, water and maybe low molecular weight hydrocarbons. The diesel obtained in this way is then mixed with hydrogen gas in the second reactor to promote a 
catalytic hydro-isomerization where a branched paraffin-rich diesel fuel is produced. The isomerized product is separated from the excess of hydrogen gas and the liquid phase is sent to the product separation section (distillation) to separate its components.

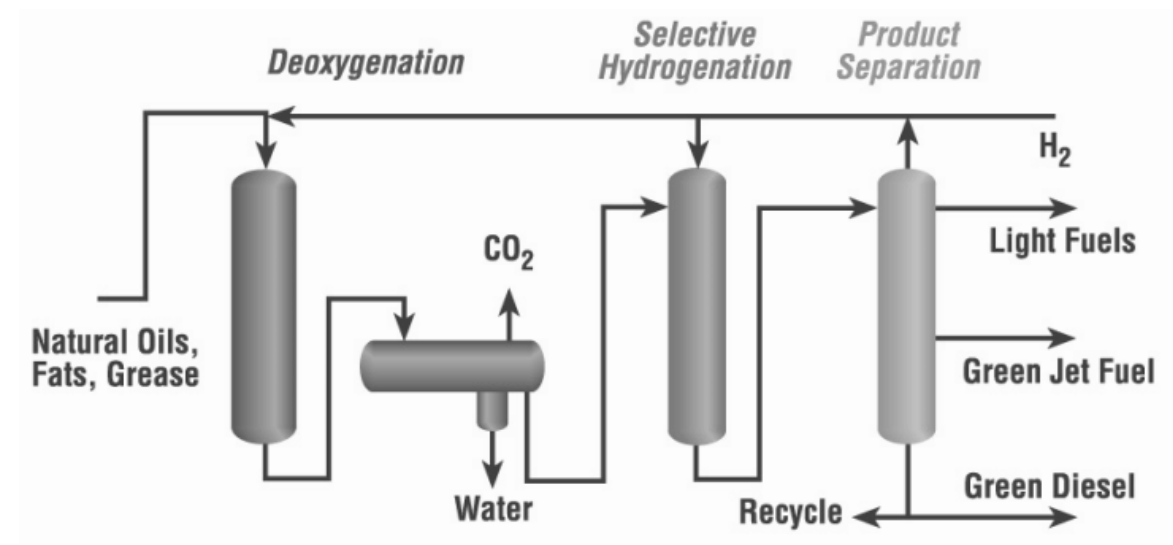

Figure 4: Green diesel produced by hydrocraking or hydrogenation [30].

\section{Nutrient Recovery from Residual Organic Matter}

This possibility was typically checked against algae growth in several standard mediums, which are recipes that provide an optimized mixture of nutrients to support microalgae growth [32].

In the scheme shown in Figure 2, apart from carbohydrates and lipids, the organic matter remaining after the processes of sugars fermentation and lipids extraction needs to be treated for a correct disposal and recycle of nutrients. Among the known processes, the most efficient to recover the nutrients and increase energy efficiency are hydrothermal liquefaction, flash hydrolysis and anaerobic digestion.

Hydrothermal Liquefaction ( $\mathrm{HTL}$ ) converts the whole microalgae biomass into biofuel while avoiding the energy-expensive step of drying the feedstock. It also leads to the production of gaseous, aqueous and solid by-products.

The yields of the HTL products depend on the conditions applied (i.e., temperature, residence time). Among them, the aqueous and solid phases contain most of the nutrients present in the feedstock, which calls for a way to recover them. Reusing the aqueous by-product after HTL would alleviate the otherwise unavoidable needs for HTL-wastewater treatment of an algae biorefinery, because of its high content in nutrients and its significant load of organic molecules [32].

$\mathrm{HTL}$ at $220-265^{\circ} \mathrm{C}$ for 30 min was used to enhance the bio-oil yield extracted from the biomass. A value of $35 \%$ was reached at $265^{\circ} \mathrm{C}$, around 2 times more than at $220^{\circ} \mathrm{C}$ (lipids present in the solid phase). The liquid phase presented a lot or organic and mineral content which could be used in the cultivation of this species [33]. The main disadvantage of HTL treatment is its high energy duty, caused by the rather strong temperature and pressure operating conditions.

Flash Hydrolysis $(\mathrm{FH})$ uses few seconds of residence time and subcritical water under heating, generally between $100-250^{\circ} \mathrm{C}$. Two fractions are obtained:

- Liquid phase: hydrolysate which contains sugars and proteins fractioned. 
- $\quad$ Solid phase: biofuels intermediate - lipids and carbohydrates [34, 35].

The advantages of this process are mostly related with the short time of heating: they include the possibility of water recycle after the process, the reduction of inhibitors formation, the production of a solid fraction richer in carbon (biofuels application) and poorer in nitrogen, which is also energetically more sustainable and can be stored for a longer period of time [35]. For instance, Scenedesmus obliquus was grown in the hydrolysate obtained from the same specie for flash hydrolysis at $280^{\circ} \mathrm{C}$ and $9 \mathrm{~s}$ of residence time. This species obtained better performance in batch cultivation than in the standard medium for autotrophic growth, thanks to the combination of heterotrophy. In continuous cultivation mode, the productivities ranged between $0.62-0.72 \mathrm{~g} /(\mathrm{L}$ day), showing satisfactory performances [36].

When anaerobic digestion is used for nutrient recycling, it is necessary to discuss about both the gas and liquid phase. Carbon dioxide (20-40\%) and methane (50-70\%) are formed during the anaerobic digestion of the biomass. Carbon dioxide may be reused for the growth of microalgae and cyanobacteria, and methane for the production of energy, in turn, may be used in any of the several heat operations within the industrial process, or for the production of electricity. At the end of the anaerobic digestion, several non-gasifiable nutrients in the operation conditions, such as $\mathrm{N}$ and $\mathrm{P}$, remain in mineral conditions in the final effluent, known as digestate, especially as ammonia and phosphate [37, 38]. They may also be used for the cultivation of microorganisms (nutrient recycling) with an increase in sustainability and autonomy of the process. For instance, Chlorella vulgaris was cultivated in sugarcane stillage anaerobically biodigested with the consumption of a great amounts of $\mathrm{N}$ and $\mathrm{P}$ of the effluent [39].

\section{DISTILLATION, CONCENTRATION, TRANSPORTATION AND USE}

Hydrous bioethanol is generally used as fuel; however, anhydrous bioethanol is better applied. Water removal during the purification step is important in a fuel concept (ethanol + gasoline mixture). The separation of a bioethanol + water mixture is not possible in a single distillation step (azeotropic mixture), but many alternative processes exist, alone or in combination, to dehydrate ethanol. Adsorption on molecular sieves, azeotropic distillation, pressure swing distillation, evaporation, extractive distillation with ionic liquids, pressure swing absorption, hybrid processes (distillation/adsorption/vapor permeation), liquid-liquid extraction, heteroazeotropic distillation using a gasoline additive as entrainer, extractive batch distillation or a heat-pump-assisted extractive distillation in a single step are cited [40].These techniques are more or less energy demanding depending on the technique and the separation requirements. A biorefinary location is defined, for the supply chain, raw material, energy and water availability, taxes, among other factors. In this sense, transportation and use steps are very important and need to be optimized in order to reduce costs of carbon emissions (fuel, mainly) and loss of ethanol (volatile) [41]. 


\section{THEORETICAL BIOETHANOL PRODUCTIVITIES}

Table 1 shows the capacity depending of the biomass type, where the productivity of bioethanol for each type of conventional biomass used and for microalgae are given. Clearly, the performances of microalgae Productivities are greater when compared to traditional biomass such as sugarcane, corn and lignocellulose biomass.

Table 1: Comparison between plants and microalgae productivities for biofuels.

\begin{tabular}{|c|c|c|c|c|}
\hline Raw Material & $\begin{array}{l}\text { Carbohydrate } \\
\text { Content } \\
\text { (\% dry biomass) }\end{array}$ & $\begin{array}{c}\text { Yield } \\
\text { (L bioethanol } \\
\text { /ton biomass) }\end{array}$ & $\begin{array}{c}\text { Land Use } \\
\text { (m² year } \\
\quad / L \\
\text { bioethanol) }\end{array}$ & $\begin{array}{l}\text { Productivity } \\
\text { (L bioethanol } \\
\text { /ha.year) }\end{array}$ \\
\hline Corn & - & 460 & 2.5 & $\begin{array}{c}3,450-4,600 \\
{[9]}\end{array}$ \\
\hline Beet & - & 100 & 1.3 & $\begin{array}{c}5,000-10,000 \\
{[9]}\end{array}$ \\
\hline Sugarcane & - & 90 & 1.2 & $\begin{array}{c}5,400-10,800 \\
{[9]} \\
\end{array}$ \\
\hline $\begin{array}{l}\text { Lignocellulosic } \\
\text { Biomass } \\
\text { (Sugarcane staw) }\end{array}$ & $50-70$ & $\sim 240$ & 1.0 & $\begin{array}{c}\sim 10,000 \\
{[42,43]}\end{array}$ \\
\hline Microalgae (LCC) & 20 & 129 & $1.40-0.47$ & $\begin{array}{c}7,093-21,279 \\
{[44]} \\
\end{array}$ \\
\hline Microalgae (MCC) & 35 & 227 & $0.80-0.27$ & $\begin{array}{c}12,413-37,286 \\
{[44]}\end{array}$ \\
\hline Microalgae (HCC) & 50 & 324 & $0.56-0.19$ & $\begin{array}{c}17,733-53,199 \\
{[44]}\end{array}$ \\
\hline $\begin{array}{l}\text { Microalgae } \\
\text { Experimental }\end{array}$ & $45-60$ & - & - & $\begin{array}{c}11,000-31,000 \\
{[45,46,47]}\end{array}$ \\
\hline $\begin{array}{l}\text { Maximum } \\
\text { Expectative for } \\
\text { Microalgae }\end{array}$ & - & - & - & $\begin{array}{c}46,760-140,290 \\
{[48]}\end{array}$ \\
\hline
\end{tabular}

LCC - low carbohydrate content, MCC - medium carbohydrate content, HCC - high carbohydrate content. BNDES [9] was used for corn, beet and sugarcane productivities. Santos et al. [42,43] (biomass lignocellulosic from sugarcane) and for microalgae Acién et al. [44] - Scenedesmus almeriensis at a productivity of 54.75-164.25 ton biomass/(ha.year) in a tubular aerated photobioreactor and temperature below $35^{\circ} \mathrm{C}$ in outdoor conditions of illumination. Maximum expectation was mentioned by Cheryl [48]. Experimental results of microalgae cultivation regarding biomass productivity was also used and the ethanol expected calculated by stoichiometry ( $1 \mathrm{~g}$ of glucose gives $0,511 \mathrm{~g}$ of ethanol (Silva and Sforza [45], Silva et al. [46] and Silva et al. [47]). 
Research on microalgae and cyanobacteria cultivation, hydrolysis and fermentation are, as a rule, the object of many investigations even though they are not currently consolidated within a continuous process, as cultivation costs are still high [49].

The stage of water and nutrient recycle and the reuse of lipids in the biomass saccharification process of sugars/lipid extraction, anaerobic digestion and energy-economic analysis of viability still lack information. Hydrolysis and saccharification need to show high yield mainly biochemical conversion of the monosaccharides (obtained after hydrolysis, acidic and enzymatic methods, mainly) to ethanol because low conversion rate has been verified [50,51]. Further investigations should be undertaken to consolidate and guarantee the viability to produce bioethanol, but they are more likely to be successful if addressed within a biorefinery approach.

Funding and Acknowledgements. The authors thank CNPq - Brazil (National Research Council of Brazil) - Process numbers 249182/2013-0 and 407274/2018-9, for resources and fellowship.

\section{REFERENCES}

1. Brennan, L.; Owende, P. Biofuels from microalgae - a review of technologies for production, processing, and extractions of biofuels and co-products. Renew. Sust. Energy Rev. 2010, 14 (2), 557-577.

2. Uenojo, M.; Pastore, G.M. Pectinases: applications and perspectives [Pectinases: aplicações e perspectivas]. Quim. Nova 2007, 30(2), 388-394.

3. Worldwatch Institute. Biofuels for Transport. Washington, D.C.: Earthscan, 2007.

4. Jonh, R.P.; Anisha, G.S.; Nampoothiri, K.M.; Pandey, A. Micro and macroalgal biomass: A renewable source for bioethanol. Bioresour. Technol. 2011, 102, 186-193.

5. Harun, R.; Danquah, M.K. Enzymatic hydrolysis of microalgal biomass for bioethanol production. Chem. Eng. J. 2011, 168, 1079-1084.

6. Ho, S.; Kondo, A.; Hasunuma, T.; Chang, J. Engineering strategies for improving the $\mathrm{CO} 2$ fixation and carbohydrate productivity of Scenedesmus obliquus CNW-N used for bioethanol fermentation. Bioresour. Technol. 2013, 143, 163-171.

7. Silva, C.E.F.; Bertucco, A. Bioethanol from microalgae and cyanobacteria. Process Biochem. 2016, 51(11), 1833-1842.

8. Gupta, A.; Verna, J.P. Sustainable bio-ethanol production from agroresidues: a review. Renew. Sust. Energy Rev. 2015, 41, 550-567.

9. BNDS. Banco Nacional de Desenvolvimento Econômico e Social. Bioetanol de cana-de-açúcar: Energia para o desenvolvimento sustentável. Rio de Janeiro: BNDS, 2008.

10. IEA. IEA Bioenergy Task 42 on biorefineries: co-production of fuels, chemicals, power and materials from biomass. Copenhagen, Denmark, 25-26, march 2007, 2008.

11. NREL. What is a biorefinary? U. S. Department of Bioenergy. Accessed 25-01-2015. Available from: http://www.nrel.gov/biomass/biorefinery.html.

12. Vitovà, M.; Bisova, K.; Kawano, S; Zachleder, V. Accumulation of energy reserves in algae: from cell cycles to biotechnological applications. Biotechnol. Adv. 2015, 6, 1204-1218. 
13. Chen, C.; Zhao, X.; Yen, H.; Ho, S.; Cheng, C.; Lee, D.; Bai, F.; Chang, J. Microalgae-based carbohydrates for biofuel production. Biochem. Eng. J. 2013, 78, 1-10.

14. Gonzalez-Fernandez, C.; Ballesteros, M. Linking microalgae and cyanobacteria culture conditions and key-enzymes for carbohydrate accumulation. Biotechnol. Adv. 2012, 30, 1655-1661.

15. Barros, A.I.; Gonçalves, A.L.; Simoes, M.; Pires, J.C.M. Harvesting techniques applied to microalgae: A review. Renew. Sust. Energy Rev. 2015, 41, 1489-1500.

16. Farooq, W.; Suh, W.I.; Park, M.S.; Yang, J. Water use and its recycling in microalgae cultivation for biofuel application. Bioresour. Technol. 2015, 184, 73-81.

17. Miranda, J.R.; Passarinho, P.C.; Gouveia, L. Pre-treatment optimization of Scenedesmus obliquus microalga for bioethanol production. Bioresour. Technol. 2012, 104, 342-348.

18. Ashokkumar, V.; Salam, Z.; Tiwari, O.N.; Chinnasamy, S.; Mohammed, S.; Ani, F.N. An integrated approach for biodiesel and bioethanol production from Scenedesmus bijugatus cultivated in a vertical tubular photobioreactor. Energy Convers. Manage. 2015, 101, 778-786.

19. Ho, S.; Huang, S.; Chen, C.; Hasunuma, T.; Kondo, A.; Chang, J. Bioethanol production using carbohydrate-rich microalgae biomass as feedstock. Bioresour. Technol. 2013, 135, 191-198.

20. Markou, G.; Angelidaki, I.; Nerantzis, E.; Georgakakis, D. Bioethanol production by carbohydrate-enriched biomass of Antrospira (Spirulina) platensis. Energies 2013, 6, 3937 3950.

21. Kim, K.H.; Choi, I.S.; Kim, H.M.; Wi, S.G.; Bae, H. Bioethanol production from the nutrient stress-induced microalga Chlorella vulgaris by enzymatic hydrolysis and immobilized yeast fermentation. Bioresour. Technol. 2014, 153, 47-54.

22. Choi, S.P.; Nguyen, M.T.; Sim, S.J. Enzymatic pretreatment of Chlamydomonas reinhardtii biomass for ethanol production. Bioresour. Technol. 2010, 101, 5330-5336.

23. Mollers, K.B.; Cannella, D.; Jorgensen, H.; Frigaard, N. Cyanobacterial biomass as carbohydrate and nutriente feedstock for bioethanol production by yeast fermentation. Biotechnol. Biofuels 2014, 7, 1-11.

24. Rippka, R.; Deurelles, J.; Waterbury, J.B.; Herdman, M.; Stainer, R.Y. Generic assignments, strain histories and properties of pure cultures of cyanobacteria. J. Gen. Microb. 1979, 111, 1-61.

25. Trevelyan, W.E.; Harrison, J.S. Studies on yeast metabolism. 1. Fractionation and microdetermination of cell carbohydrates. Biochem. J. 1952, 50(3), 298-303.

26. Moncada, J.; Tamayo, J.A.; Cardona, C.A. Integrating first, second, and third generation biorefineries: incorporating microalgae into the sugarcane biorefinery. Chem. Eng. Sci. 2014, 118, 126-140.

27. Lorente, E.; Farriol, X.; Salvado, J. Steam explosion as a fractionation step in biofuel production. Fuel Process. Technol. 2015, 131, 93-98.

28. Wang, H.; Ji, C.; Bi, S.; Zhou, P.; Chen, L.; Liu, T. Joint production of biodiesel and bioethanol from filamentous oleaginous microalgae Tribonema sp. Bioresour. Technol. 2014, 172, 169-173.

29. Biofuels Digest (Jim Lane). Diamond Green Diesel starts up, largest advanced biofuels facility goes online. Accessed 06-17-2016. Available from: http://www.biofuelsdigest.com/bdigest/2014/05/15/diamond-green-diesel-starts-up-largest-adva nced-biofuels-facility-goes-online/. 
30. Biomass Magazine (Anna Simet). Honeywell jet fuel powers world cup flights. Accessed 06-17-2016.

Available

from: http://biomassmagazine.com/articles/10578/honeywell-jet-fuel-powers-world-cup-flights.

31. Honeywell Green Diesel. Honeywell UOP. Accessed 06-17-2016. Available from: http://www.uop.com/processing-solutions/renewables/green-diesel/\#biodiesel.

32. Barreiro, D.L.; Bauer, M.; Hornung, U.; Posten, C.; Kruse, A.; Prins, W. Cultivation of microalgae with recovered nutrientes after hydrothermal liquefaction. Algal Res. 2015, 9, 99-106.

33. Ramos-Tercero, E.A.; Bertucco, A.; Brilman, D.W.F. Process water recycle in hydrothermal liquefaction of microalgae to enhance bio-oil yield. Energy Fuels 2015, 29(4), 2422-2430.

34. Kumar, S.; Gupta, R.B. Hydrolysis of microcrystalline cellulose in subcritical and supercritical water in a continuous flow reactor. Ind. Eng. Chem. Res. 2008, 47(23), 9321-9329.

35. Garcia-Moscovo, J.L.; Obeid, W.; Kumar, S.; Hatcher, P.G. Flash hydrolysis of microalgae (Scenedesmus sp.) for protein extraction and production of biofuels intermediates. J. Supercrit. Fluids 2013, 82, 183-190.

36. Barbera, E.; Sforza, E.; Kumar, S.; Morosinotto, T.; Bertucco, A. Cultivation of Scenedesmus obliquus in liquid hydrolysate from flash hydrolysis for nutrient recycling. Bioresour. Technol. 2016, 207, 59-66.

37. Silva, C.E.F.; Abud, A.K.S. Anaerobic biodigestion of sugarcane vinasse under mesophilic conditions using manure as inoculum. Revista Ambiente \& Água 2016, 11(4), 763-777.

38. Moraes, B.S.; Zaiat, M.; Bonomi, A. Anaerobic digestion of vinasse from sugarcane ethanol production in Brazil: Challenges and perspectives. Ren. Sust. Energy Rev. 2015, 44, 888-903.

39. Marques, S.S.I.; Nascimento, I.A.; Almeida, P.F.; Chinalaia, F.A. Growth of Chlorella vulgaris on sugarcane vinasse: the effect of anaerobic digestion pretreatment. Appl Biochem Biotechnol 2013, 171, 1933-1943.

40. Gomis, V.; Pedraza, R.; Saquete, M.A.; Font, A.; Garcia-Cano, J. Ethanol dehydration via azeotropic distillation with gasoline fraction mixtures as entrainers: A pilot-scale study with industrially produced bioethanol and naphta. Fuel Process. Technol. 2015, 140, 198-204.

41. Bargos, F.F.; Lamos, W.Q.; Bargos, D.C.; Neto, M.B.; Pardal, P.C.P.M. Location problem method applied to sugar and ethanol mills location optimization. Ren. Sust. Energy Rev. 2016, 65, 274-282.

42. Santos, F.A.; Queiroz, J.H.; Colodette, J.L.; Fernandes, A.S.; Guimaraes, V.M.; Rezende, S.T. Potencial da palha de cana-de-açúcar para produçao de etanol. Quim. Nova 2012, 35(5), 1004-1010.

43. Santos, F.A.; Queiròz, J.H.; Colodette, J.L.; Manfredi, M.; Queiroz, E.L.R.; Caldas, C.S.; Soares, F.E.F. Otimização do pré-tratamento hidrotérmico da palha de cana-de-açúcar visando à produção de etanol celulósico. Quim. Nova 2014, 37(1), 56-62.

44. Acién, F.G.; Fernandéz, J.M.; Magàn, J.J.; Molina, E. Production cost of a real microalgae production plant and strategies to reduce it. Biotechnol. Adv. 2012, 30, 1344-1353.

45. Silva, C.E.F.; Sforza, E. Carbohydrate productivity in continuous reactor under nitrogen limitation: Effect of light and residence time on nutrient uptake in Chlorella vulgaris. Process Biochem. 2016, 51, 2112-2118. 
46. Silva, C.E.F.; Sforza, E.; Bertucco, A. Stability of carbohydrate production in continuous microalgal cultivation under nitrogen limitation. Effect of irradiation regime and intensity on Tetradesmus obliquus. J. Appl. Phycol. 2018, 30, 261-270.

47. Silva, C.E.F.; Sforza, E.; Bertucco, A. Continuous cultivation of microalgae as an efficient method to improve carbohydrate productivity and biochemical stability. Proceedings of the $25^{\text {th }}$ European Biomass Conference and Exhibition, Stockholm, Sweden, 12-15 June 2017.

48. Cheryl. Algae becoming the new biofuel of choice. 2008. Accessed: 25 Feb 2016. Available online: http://duelingfuels.com/biofuels/non-food-biofuels/algae-biofuel.php

49. Tercero, E.A.R.; Domenicali, G.; Bertucco, A. Autotrophic production of biodiesel from microalgae: An update process and economic analysis. Energy 2014, 76, 807-815.

50. Silva, C.E.F.; Meneghello, D.; Bertucco, A. A systematic study regarding hydrolysis and ethanol fermentation from microalgal biomass. Biocatal. Agric. Biotechnol. 2018, 14, 172-182.

51. Silva, C.E.F.; Bertucco, A. Dilute acid hydrolysis of microalgal biomass for bioethanol production: an accurate kinetic model of biomass solubilization, sugars hydrolysis and nitrogen/ash balance. React. Kinet. Mech. Cat. 2017, 122, 1095-1114.

(C) 2018 by the authors. Submitted for possible open access publication under the terms and conditions of the Creative Commons Attribution (CC BY NC) license (https://creativecommons.org/licenses/by-nc/4.0/). 